\title{
Repair scars on Mactra violacea from the eastern coast of India: A new classification and a model for describing shell breakage on bivalves
}

\author{
Subhronil Mondal, Subhendu Bardhan, Sumanta Mallick, and Arindam Roy
}

\begin{abstract}
Non-lethal shell damage, which is preserved as repair scars on the bivalve shell, can be predatory or non-predatory in origin. When the peeling crabs are the main predatory groups, non-predatory damages are produced by impact from the saltating clasts or by wear and tear during burrowing. In both cases, these repair scars almost look alike, and it is difficult to identify which factor is causally responsible. Because survival of an individual is related to the severity of the shell-break irrespective of the cause, here, we have developed a classificatory scheme to categorize the repaired traces on the basis of intensity of the damage. Moreover, we have provided a model to analyze how the severity of scars can be effectively used to study species' adaptation against shell breaking causes, by using Mactra violacea as a studied species. Individuals who survive shell breakage may adapt to escalated morphological traits to resist damage in the long term.
\end{abstract}

Subhronil Mondal. School of Geosciences, University of South Florida, 4202 E. Fowler Ave. NES107, Tampa, FL 33620-5250, USA. subhronil.m@gmail.com

Subhendu Bardhan. Department of Geological Sciences, Jadavpur University, Kolkata-700032, India. sbardhan12@gmail.com

Sumanta Mallick. Department of Geological Sciences, Jadavpur University, Kolkata-700032, India. sumanta.geol87@gmail.com

Arindam Roy. Department of Geological Sciences, Jadavpur University, Kolkata-700032, India. addy.geol@gmail.com

Keywords: shell break; Indian coast; size-refuge; prey effectiveness

\section{INTRODUCTION}

Repaired shell breaks, called scars, indicate sub-lethal shell damage which the organism was able to repair. There are multiple causes which can create this kind of damage in modern bivalve assemblages (Zuschin et al., 2003). While abioti- cally-induced damage is generated by physical factors such as wear and tear during burrowing (Checa, 1993; Cadee et al., 1997; Cadee, 1999), impact by wave borne clasts (Cadee, 1999), or human activities (Ramsay et al., 2000). Biotically induced repair scars are attributed to unsuccessful 
attacks by the shell breaking predators (Vermeij, 1983; Vermeij and Dudley, 1985; Ebbestad and Peel, 1997; Dietl et al., 2000; Paul et al., 2013; and many others). In most cases, it is difficult to identify the taxonomic affinity of the 'culprit' just by looking at these scars (Kowalewski, 2002). The causes of shell breakage have been linked to the life habit of the prey. For example, the shell breaks of deepinfaunal species, which live outside the reach of potential shell-breaking predators, are thought to be non-predatory in origin (Checa, 1993; Alexander and Dietl, 2001, 2005). Although this assumption is safe for deep-infaunal bivalves, the cause of scarring is difficult to interpret for epifaunal, shallow and semi-infaunal bivalves, which can suffer shell breaks by both predation and physical factors (see Ausich and Gurrola, 1979 for an example). Moreover, these two types of scars often have indistinguishable morphologies. For example, nonpredatory arcuate or angular types of scars are similar to predatory scalloped type. Due to this apparent similarity, some authors, in fact, have synonymized some of these terminologies (Alexander and Dietl, 2001, 2003; Dietl, 2003, 2004). In addition, the classification schemes are often subjective and difficult to quantify. Under these circumstances, attempt of classification of repaired traces based on their causes will only "distract us from the real strength of trace fossils" (Kowalewski, 2002). Irrespective of the cause (i.e., abiotic or biotic) these breaks will affect survival during subsequent encounters with enemies and the environment (see Kowalewski, 2002). Survival may enhance the chances of reproduction of the individuals of the species and contribute to the adaptation against shell breaks in the long run (Vermeij, 1982).

Here, we have studied scars on a shallowburrowing bivalve, Mactra violacea Gmelin, 1791, from the Indian coast, and have demonstrated that our studied species showed signatures of both the predatory and non-predatory scars on them (i.e., heterogeneity of scars). We have argued that it is not required to classify scars based on their origin. Rather, it is important to focus on the severity of scars and correlate those with the survival of inflicted bivalves (see Mondal et al., 2010a for similar approach). In line with that, we have introduced a new classification system of scars based on their severity irrespective of their cause. In fossil record, when this type of heterogeneity of scars is encountered, we can use our new classificatory scheme to study the adaptation of a species against shellscarring agents.

\section{MATERIAL AND METHODS}

\section{The Opportunity}

Chandipur, located on the eastern coast of India $\left(21^{\circ} 30^{\prime} \mathrm{N}, 86^{\circ} 54^{\prime} \mathrm{E}\right)$, has a vast expanse of tidal flat within an estuary-bar complex (Figure 1). A diverse assemblage of predators and prey inhabit this area (Mondal et al., 2010b; Das et al., 2014). The bivalve community is represented mostly by the genus Mactra. Mactra violacea is generally less abundant and found sporadically as disarticulated shells (mostly adults) along the beach and the tidal flat. This species is large and is shallow burrower (i.e., the distance between sediment-water interface and the posterior end of the buried shell is not great), living in the intertidal to sub-tidal muddy-shaly sand flats in Chandipur (Rao et al., 1991, 1992). However, in a recent study from other parts of India, it was observed that adult $M$. violacea lives in the surf zone, which is frequently disturbed by the tidal waves (Laxmilatha et al., 2010). M. Violacea burrows a considerable depth (the adult length may exceed $8.5 \mathrm{~cm}$.) to make it fully infaunal and for this reason may be alternatively considered as a deep burrowing bivalve (cf. Stanley, 1970; Ingole, 2002; Laxmilatha et al., 2010). However, the individuals in Chandipur do not live far away from the sediment-water interface. Two lines of evidence further support our observation. First, the shells are occasionally found with drillholes made by naticid gastropods which hunt only within shallow sediments. Second, $M$. violacea has quite large and thick shell, which is related to shallow depth of burial (Stanley, 1970, figure 30). Shallow burrower bivalves evolved thicker shell to avoid boring gastropods and physical shell breakage (Carter, 1968; Stanley, 1970). M. violacea has smooth shells, although in some specimens faint divaricate-like ribs seem to appear near the venter (personal observation). A thick periostracum layer is present over the shell. M. violacea has a slit-like anterior and an oval posterior gape (Figure 2). In Chandipur, the species generally shows low frequency of drilling predation with respect to other species of Mactra (see Mondal et al., 2010b; personal observation). Present specimens, however, have extensive scars on them (Figures 2, 3).

During July-August (2009), a strong monsoonal cyclone, named locally as 'Aila' in India, exhumed a vast assemblage of $M$. violacea at Chandipur from its intertidal and subtidal habitats (Ingole, 2002) and was brought on to the beach. Tens of hundreds of adult $M$. violacea were washed ashore along the highest water marks (near back- 


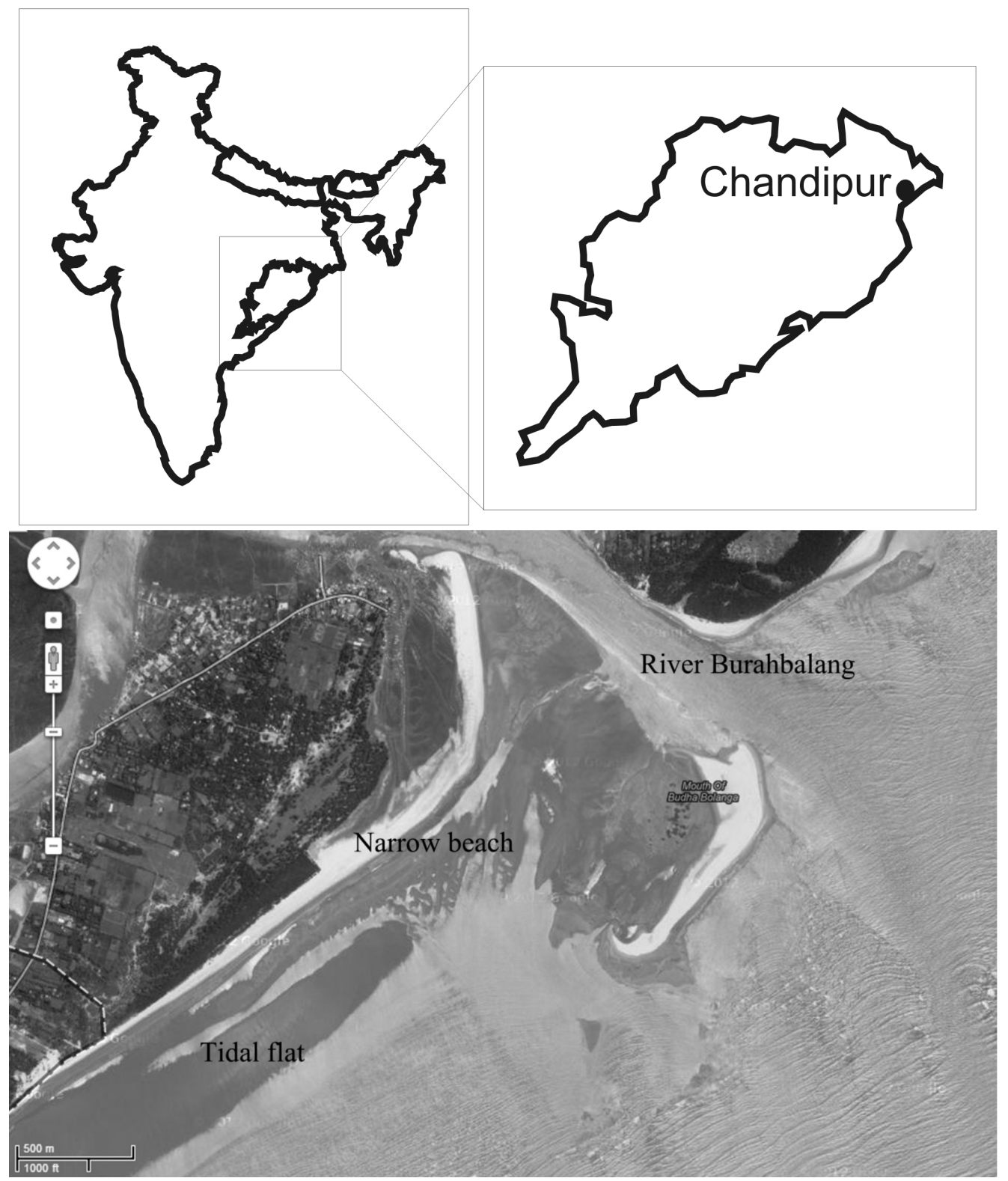

FIGURE 1. Map of the studied area with beach-bar-tidal flat-back swamp. The actual photograph is taken from the Google Earth (2013).

shore-aeolian dune transition). This provided a rare opportunity to study a population of $M$. violacea, which are relatively rare through the seasons in the beach. This taphonomic assemblage (Taphonomoic Grade I, Flessa et al., 1993) was almost monotypically composed of $M$. violacea. Most of the shells were articulated, and even retained ligament and periostracum on them. A total of 533 articulated shells (antero-posterior length varies from $30 \mathrm{~mm}$ to $85 \mathrm{~mm}$ ) were collected systematically through five grids $(1 \mathrm{~m} \times 1 \mathrm{~m})$, which were aligned parallel to the beach every $50 \mathrm{~m}$. Younger specimens (antero-posterior length $<20 \mathrm{~mm}$ ) were also collected from outside the grid to document ontogenetic changes of morphological traits, as well as shell repair data.

\section{Probable Origin of Scars}

In life orientation, the sagittal plane of $M$. violacea remains vertical with the posterior part of the shell being close to the sediment-water interface. Because of the presence of the prominent gape at the posterior, predator-induced scars are likely to be concentrated along this region (Alexander and Dietl, 2001; Boulding, 1984). In addition, if the scars are mirror-image on both valves, it is another 


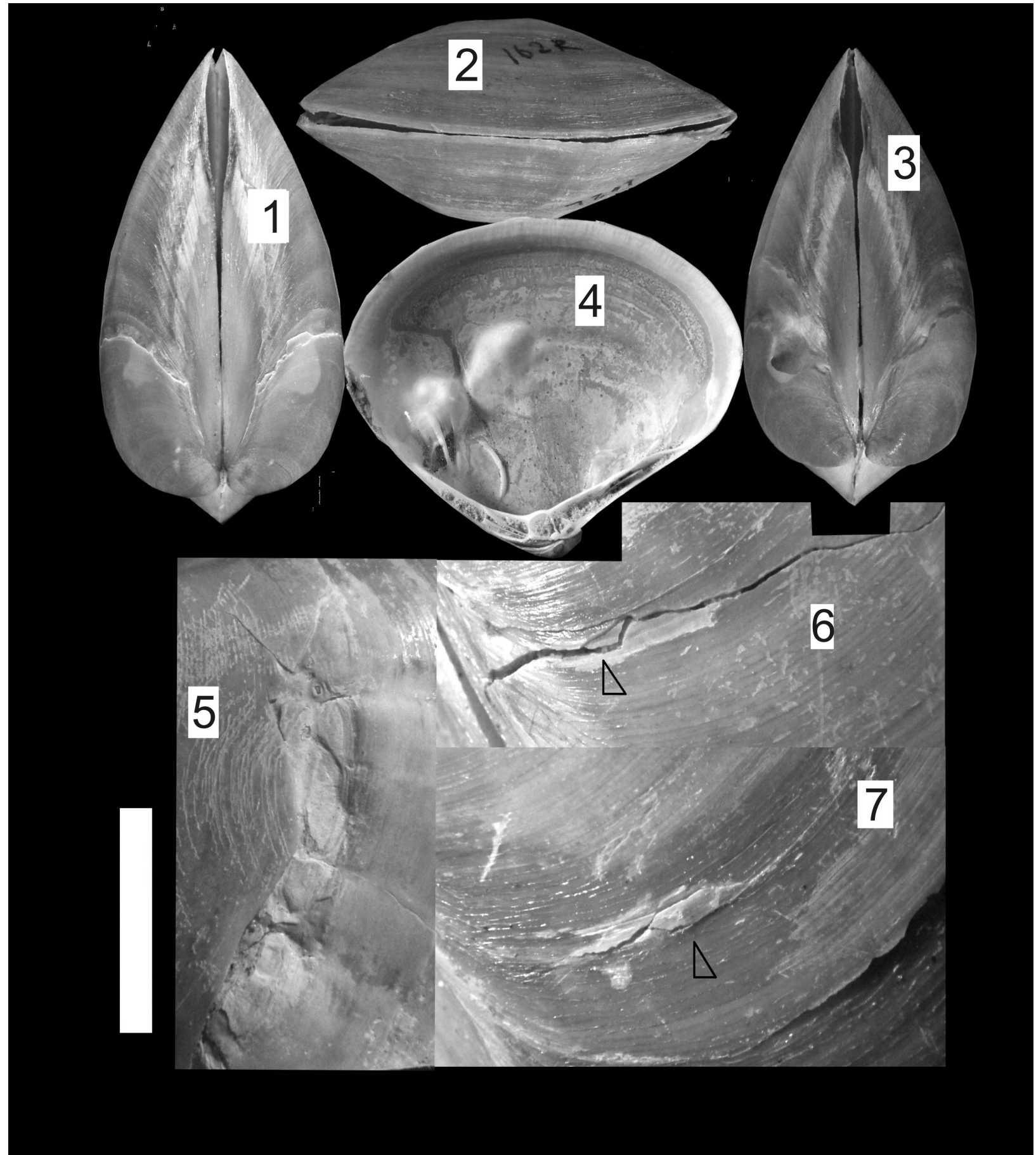

FIGURE 2. Several types of damages on the bivalve shells have been used as an indicator of breaks. 1-3,valves are gaped even when they are closed, 1 and 3, scars are mirror imaged on two valves; 4,internal view of the bivalve shows sign of repair due to severe break (visible at the external side); 5 , a severe break (Grade I) has been repaired by carbonate secretion; 6-7, retention of broken fragment near a large break (arrows).

strong indicator of predation (Leighton, 2001). Another most common feature in support of predation is size refuge, i.e., whether shell breaks are restricted to any particular size class or not (Leighton, 2001). Since predators tend to attack a pre- ferred prey size (i.e., size selectivity), predatory attacks seem to concentrate at a particular size class of the prey (Leighton, 2001). Alternatively, if damage was mostly non-predatory, we should find shell breaks throughout the ontogeny of the spe- 


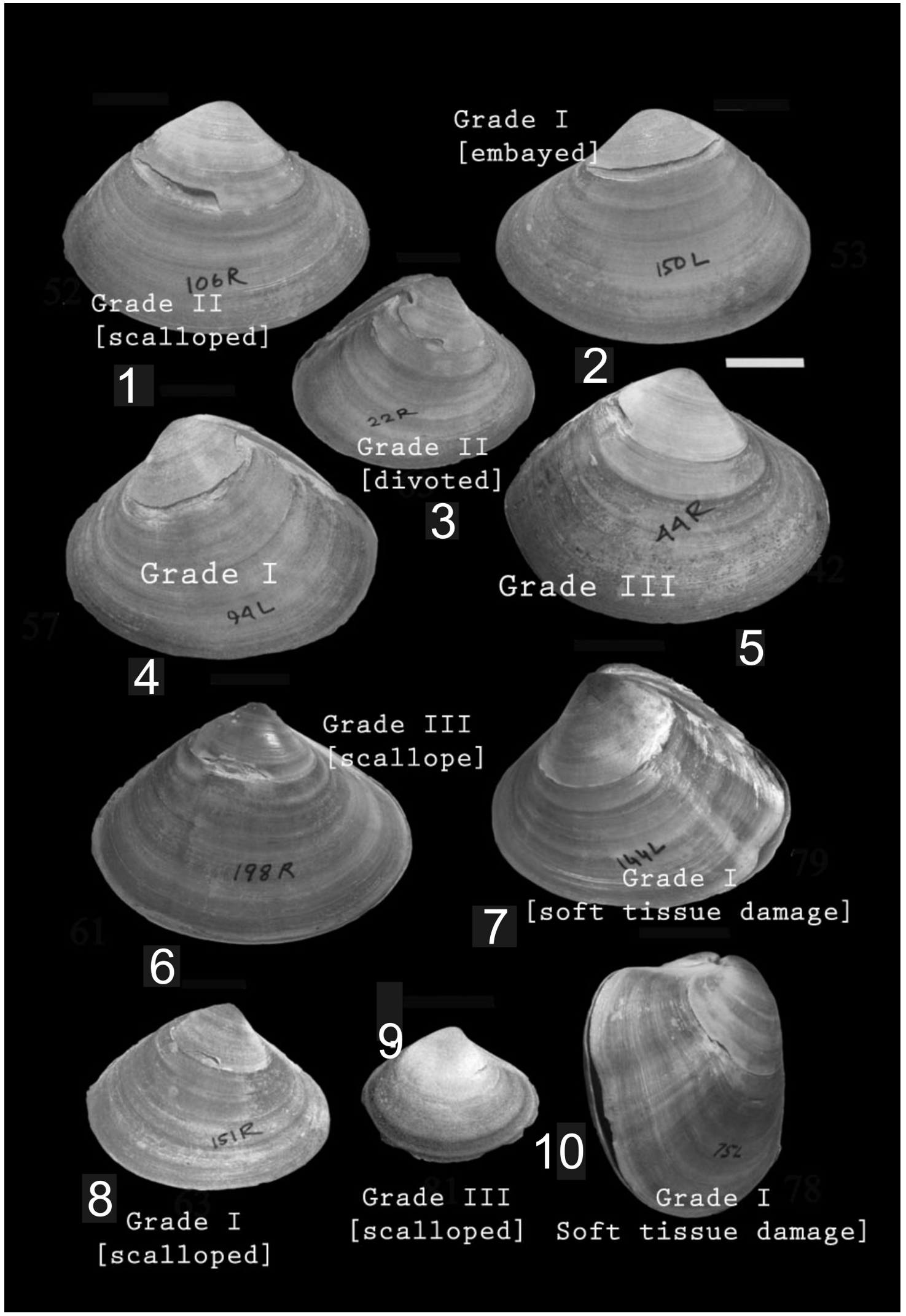

FIGURE 3. Different types of repair scars on Mactra violacea are presented here. See that the valves (7 and 10) have distinct undulation because of a severe break (Grade I). 

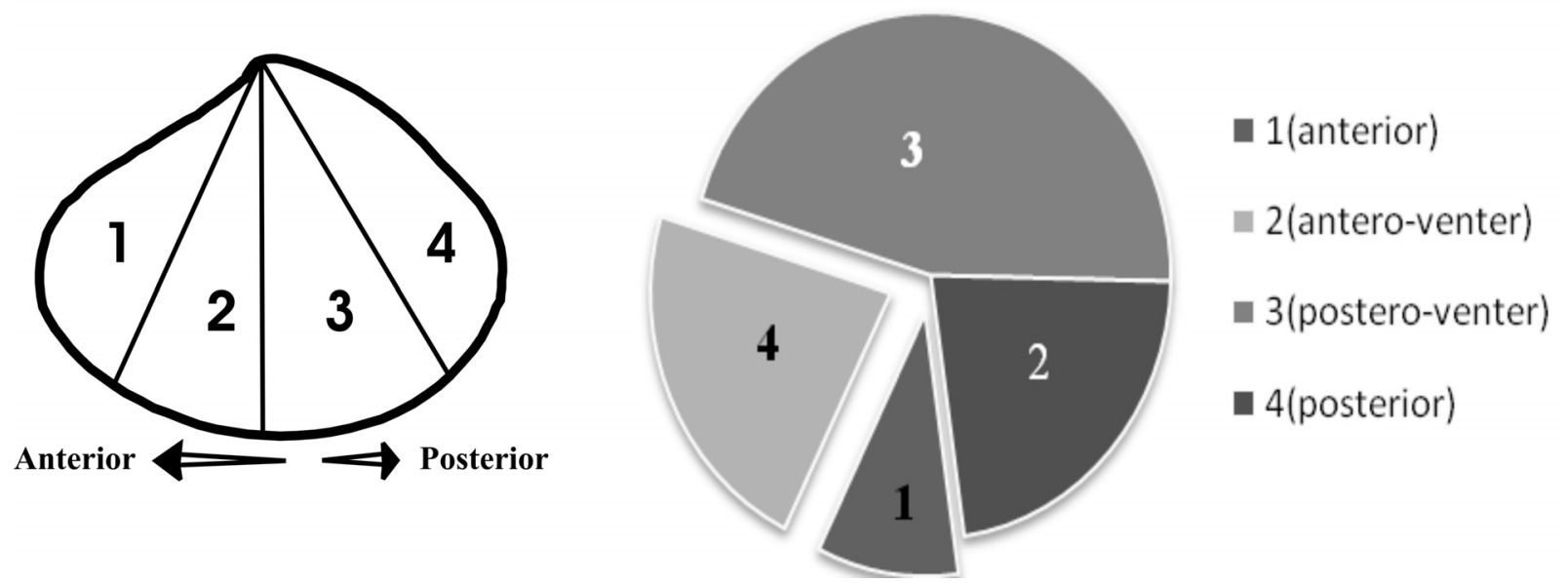

FIGURE 4. Schematic diagram of the studied species, Mactra violacea, shows scar distribution (the pie chart at right) on the valves (i.e., the grids at left). Note that the venter (location 2 and 3 together) has maximum number of scars.

cies. Distribution of scars on the prey shell in that case, however, will be higher at smaller individuals under the same physical influences. For this, documentation of ontogenetic distribution of scars is required.

In order to document size refuge of scars, we have measured length (anterior-posterior elongation) of the dead shells and length of the shells at the age when the scars were produced (Figure 4). These have been treated as 'length at death' and 'length at scar', respectively (see Alexander and Dietl, 2001). Skewness of size-frequency distributions of these two measurements was compared by means of a statistical t-test (Figure 4; see also Alexander and Dietl, 2001) to see whether scars are restricted to a particular size class or not. To document whether scars are distributed throughout the shell or are locally concentrated on a particular location of the shell (site-specificity), valves have been divided into four distinct sectors/grids (Figure 4) and numbers of scars on these locations were recorded. If the length of a scar stretches from the antero-venter to the postero-venter, and thus covers the whole venter (Figure 3.4), we counted this as four scars, one in each sector (see Mondal and Herbert, 2012). In doing so, a single scar may be represented as a maximum of four separate scars at four locations, which might increase true number of scars on the species, but will represent the damaged locations of the shell. Otherwise, an entirely broken venter and a small scalloped breakage will be weighted the same, which will not separate scars based on their severity. Chi-square goodness of fit test was performed to see whether scars are randomly distributed to the shells or not, with $\alpha$ $=0.05$. It should be noted that, for the present case, in most individuals, scars are present as mirror images on both valves, without showing any valve preference (Figure 2.1, 2.3). For this reason, either of the two valves (left or right, no bias) of the articulated specimens was studied for the location of scars.

\section{The Proposed Classification Scheme}

Based on their severity, repair scars were categorized under three groups: Grade I, Grade II, and Grade III (Table 1; Figure 3). These categories are gradational. Grade I is the most severe one because it inflicts damage to the soft parts, which may be exposed to bacteria, parasites, and predators (Vermeij, 1983, 1987; Dietl and Alexander, 2005). It also includes very large-sized scars-

TABLE 1. Types of shell damages, separated by different Grades, introduced in the paper.

\begin{tabular}{|c|c|c|c|c|c|}
\hline \multirow[b]{2}{*}{ Grade } & \multicolumn{3}{|c|}{ Characters of scars } & \multicolumn{2}{|c|}{ Synonyms } \\
\hline & $\begin{array}{l}\text { Soft tissue } \\
\text { damage }\end{array}$ & $\begin{array}{c}\text { Stretch } \\
\text { (with respect to length) }\end{array}$ & $\begin{array}{c}\text { Depth } \\
\text { (with respect to width) }\end{array}$ & Predatory & Non-Predatory \\
\hline 1 & visible & $>50 \%$ & $>30 \%$ & Embayed, Cleft & Creases, Arcuate-angular \\
\hline II & --- & $5-50$ & $5-30 \%$ & Scalloped, Devoted & Horseshoe \\
\hline III & --- & $<5 \%$ & $<5 \%$ & Scalloped & Arcuate-angular \\
\hline
\end{tabular}


embayed and cleft type scars of predatory origin, by Alexander and Dietl (2001); and creases and arcuate-angular type of scars of non-predatory origin by Checa (1993). A scar with elongation greater than or equal to $50 \%$ of body length (here antero-posterior length) and/or a depth (from venter towards umbo) of greater than or equal to $30 \%$ of the shell height (here distance of umbo from ventral commissure) is considered as Grade IA. Soft part damage (identified externally or internally by shell distortion, or offset in growth lines or double wall) is considered as Grade IB.

Grade II is less severe than Grade I. Grade II includes scars which cover $5-50 \%$ of body length and/or depth between $5-30 \%$ of shell height (Table 1). It does not inflict any soft part damage, but a large portion of the shell is chipped away. It includes scalloped and divoted type of scar of predatory origin (Alexander and Dietl, 2001) and horseshoe type of non-predatory scars (Checa, 1993).

Grade III is the least severe type of damage, which indicates a very small break or removal of small slivers of the shell ( $<5 \%$ of length and height; Table 1). It includes scalloped (Dietl and Alexander, 2005) and arcuate-angular type (Checa, 1993) scars. Chi-square goodness of fit test was performed to see whether all grades of scars are equally common on the shells or not.

\section{Species' Adaptive Responses against Breaks}

Shell morphologies were studied to correlate them with the scars. Shell convexity and thickness near the ventral commissure were studied as proxy of the shell strength (Alexander and Dietl, 2003). Valve convexity was measured as ventral angles at several ontogenetic stages. Shell thickness at venter was calculated using digital slide calipers $(0.01$ precision). Depth of pallial sinus was calculated for different growth stages in order to examine the relative change in burrowing depth with age (Stanley, 1970). In general, a thicker shell is more resistant against shell break; less convex valves are helpful for rapid burrowing, and deep infaunal forms are less likely to be attacked by the predators.

\section{RESULTS AND DISCUSSION}

\section{Probable Origin of Scars}

Scars are non-randomly distributed on the bivalve shells $\left(X^{2}=97.062, p<0.01\right)$ with $9.52 \%$ of the scars located on the anterior part of the shell (near the anterior gape; location 1 in Figure 4) and $22.4 \%$ of the scars found within the posterior part (near the posterior gape, location 4). The venter (location 2 and 3 together) has as many as 243 scars $(68.06 \%)$. Out of these ventrally-located scars, $163(45.66 \%)$ are located in the posteroventral location (i.e., location 3 ).

When frequencies of 'length at death' and 'length at scar' are plotted (Figure 5), the length at death distribution showed positive skewness (right), and the length at scar distribution showed negative (left) skewness. The difference between mean size of length at death $(65.55 \mathrm{~mm})$ and length at incidence of scars $(31.73 \mathrm{~mm})$ is significant (t-test, $p<0.01)$. Apparently, no size refuge is observed (see Figure 5), suggesting that shell breakage continued throughout the whole ontogeny of the individual. For this reason, it is thought that the cause is non-predatory. However, low intensities of scars on the relatively larger shells (i.e., length> $50 \mathrm{~mm}$ ) may be the result of attacks by certain group of predator(s) who only attack the larger individuals.

Further support of non-predatory origin of scars include retention of broken chips at the damaged area (Figure 2.5-7), which is not the characteristic feature of peeling predation (e.g., crabs) and is more characteristic of abiotic damage (Checa, 1993). Periostracum and/or any other organic matrix help to retain these broken chips. The other evidence is that $M$. violacea is a shallow burrower with a permanent posterior gape. If the epifaunal predatory peeling crabs were the culprits, the scars will be mostly restricted at the posterior part of the shell; for prey with a posterior gape will be broken from the gape (see Boulding, 1984). Contrary to this, we have found only $22.4 \%$ of scars at the posterior part. The presence of the maximum number of scars at the ventral part of the shell might have been produced during burrowing (Checa, 1993; Alexander and Dietl, 2001); however we did not find any live individual of the species to test that hypothesis. Other evidence in favor of abiotic origin of scars is that some shells show characteristic non-predatory post-mortem cracks (from venter towards umbo) at the vicinity of boulders in the beach (pers. obs.), further implying that the non-predatory shell-breaking agents could have interacted while the individuals were still alive. Moreover, the studied area suffers from extensive anthropogenic activities (i.e., fishing, trawling, dredging, and trampling), which might cause physical breakage (Ramsay et al., 2000, 2001).

However, many of the individuals show signs of predatory origin of the scars. As mentioned ear- 


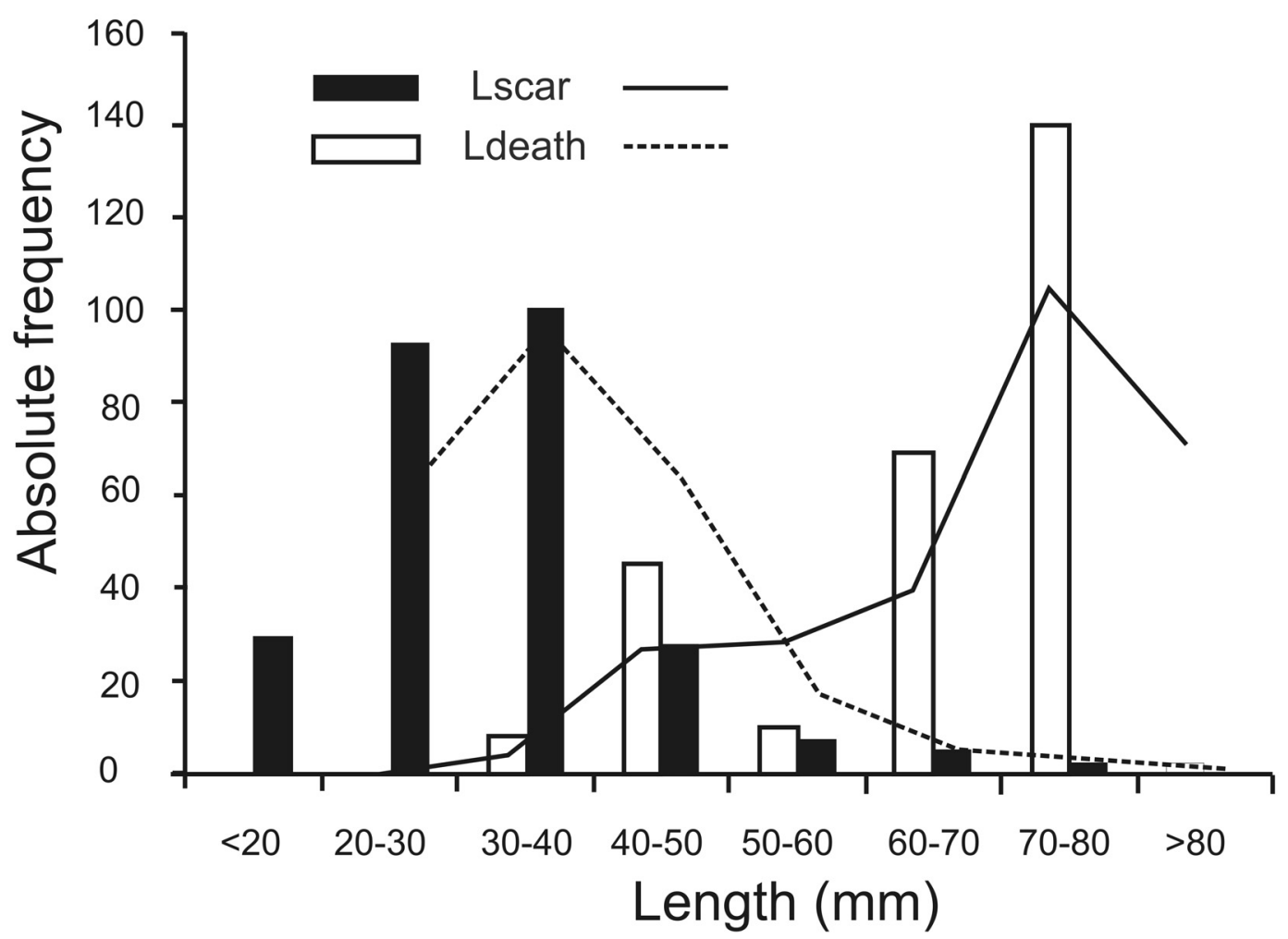

FIGURE 5. The graph shows absolute frequency distribution of 'length at death' and 'length at the incidence of scarring' on bivalve shells. Note marked differences in absolute frequency distributions of these two lengths. Presence of non-random distribution of 'length at death' indicates that the samples are not winnowed from the actual habitat of the living bivalves.

lier, the high concentration of scars at the posterior part relative to the anterior of infaunal bivalves is a probable indicator of predatory origin (Alexander and Dietl, 2001). Other evidences in support of the possible predatory origin are: (1) severe soft tissue damage, which create shell distortion, growth line discontinuity, abnormal shell growth, absence of ornamentation, and permanent failure of complete repairing (Figures 2.4-5, 3.5-10); (2) scars are present as mirror images on both valves (Leighton, 2001). The other evidences are the morphology of the scars themselves. As reported by many paleontological and neontological studies (Vermeij, 1982; Alexander and Dietl, 2001; Paul et al., 2013; Mondal et al., 2014b), peeling predators use their claws to chip away small portion of the shell during feeding (Vermeij, 1977; Zipser and Vermeij, 1978; Seed and Hughes, 1995; Sanford et al., 2003). As a consequence, biotically produced repair scars, similar to which have been documented here, are not parallel to the growth lines and show zigzag pattern of break (Figures 2, 3). The other evidence which further supports the biotic origin of these scars is that the majority of scars are concentrated at earlier ontogeny, which might indicate a case of size-refuge (Figure 5) related to predation (Leighton, 2001). Chandipur has diverse groups of durophagous predators, including crabs (see Mondal et al., 2010b for references), which might be responsible for this jagged scars (Vermeij, 1982; Boulding, 1984). Other probable predators are the Busyconinae gastropods, which may chip the shell margin away during feeding (see Dietl, 2004). All these potential factors suggest a mixed mode of breakage for $M$. violacea. The exact proportion of predatory to non-predatory damage is difficult to count, but it indicates a clear heterogeneity of shell damage, including both the predatory and nonpredatory types.

\section{Severity of Scars and Related Adaptations}

Grade III is the most common type of scar (almost 60\%), while Grade II scar is relatively infrequent $(22 \%)$ and Grade I scar is rare $(<18 \%)\left(X^{2}=\right.$ 
TABLE 2. Distribution of damages and their severities are presented here. Note that most the damages are of Grade III and are concentrated on the ventral part of the shell. Stretch $=$ the dimension of the scar (see text).

\begin{tabular}{|c|c|c|c|c|c|c|c|}
\hline \multirow{3}{*}{ Grade } & \multicolumn{7}{|c|}{ Location on shell } \\
\hline & \multirow[t]{2}{*}{1} & \multicolumn{2}{|c|}{2} & \multicolumn{2}{|c|}{3} & \multicolumn{2}{|c|}{4} \\
\hline & & $\begin{array}{l}\text { Type A (stretch } \\
\text { and depth) }\end{array}$ & $\begin{array}{c}\text { Type B (soft } \\
\text { tissue damage) }\end{array}$ & $\begin{array}{l}\text { Type A (stretch } \\
\text { and depth) }\end{array}$ & $\begin{array}{c}\text { Type B (soft } \\
\text { tissue damage) }\end{array}$ & $\begin{array}{l}\text { Type A (stretch } \\
\text { and depth) }\end{array}$ & $\begin{array}{c}\text { Type B (soft } \\
\text { tissue damage) }\end{array}$ \\
\hline 1 & 2 & 12 & 3 & 20 & 5 & 14 & 3 \\
\hline II & 7 & \multicolumn{2}{|c|}{18} & \multicolumn{2}{|c|}{32} & \multicolumn{2}{|c|}{18} \\
\hline III & 25 & \multicolumn{2}{|c|}{47} & \multicolumn{2}{|c|}{106} & \multicolumn{2}{|c|}{45} \\
\hline
\end{tabular}

137.412, p $<0.01)$. Soft tissue damage is also very rare (only 11 out of 533 scars, Table. 2). Table 2 also suggests that scars of different grades are not site specific; they may be present anywhere on the shell.

The species shows high frequency of less severe scars (Grade III), which indicates the species' effectiveness against shell breaking agents (Table 2) and high repairability (Alexander and Dietl, 2001; Mondal et al., 2010a) against sublethal breaks. This enhances an individual's survival and longevity even it suffers maximum damage at early ontogeny (Figure 4). If breakage is severe (i.e., Grade I and II), it would have decreased the probability of survival of individuals and the length at death would have been restricted at the early ontogeny (where scars were concentrated) (see the section 'A Model' below). Moreover, depth of pallial sinus, shell thickness, and the ventral angle (as an indicator of shell convexity) show ontogenetic increase (Figure 6). M. violacea has a large and relatively thick shell, which increases shell strength against breaking irrespective of the agent. All these are indicative of breakage-resistant adaptations of the species.

\section{A MODEL}

It now appears that various abiotic processes can result in shell breaks that can be very similar in morphology with breaks produced by the shellbreaking predators (Alexander and Dietl, 2001, 2003; Dietl, 2003, 2004; see also Kowalewski, 2002). Even more, different predators can produce similar type of breakage (Kowalewski, 2002), and members of the same species of predator can produce morphologically variable traces (e.g., Bromley, 1970; Zipser and Vermeij, 1978; Alexander,
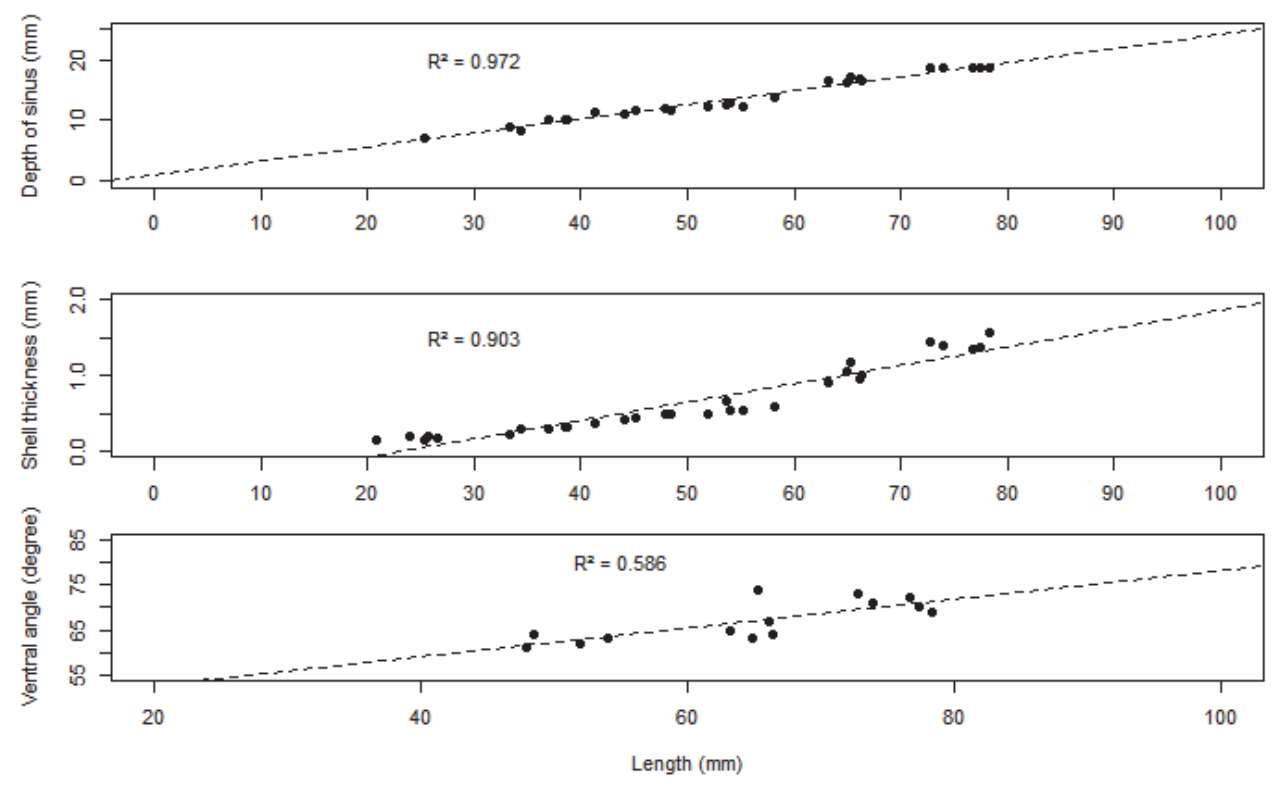

FIGURE 6. Ontogenetic changes in $M$. violacea. The figures indicate changes in depth of living, shell thickness at venter and ventral angle with ontogeny, supporting lower incidence of shell damages. 
1986; Dietl and Kelley, 2006; Kowalewski et al., 1997; Grey et al., 2005; Morton, 2005; Dietl and Kelley, 2006; Grey et al., 2007; Mondal et al., 2014a). As a consequence, misidentification of the cause of those scars can overestimate or underestimate predation frequencies of any prey species (Mondal et al., 2014b). As Kowalewski (2002) has pointed out, identification of causes of scarring is not always required, because "....such identification efforts can only distract us from the real strength of trace fossils" (p. 10). Whatever might be the cause, severity of scars will determine an individual's longterm survival and subsequent adaptation.

Alexander and Dietl (2001) came up with a unique way of using the frequency distribution of length of scars in relation with the frequency distribution of length at death, so that, when compared, these two distributions (their figure 1) can be used as a measure of species' adaptive capability, which they called as 'repairability' (see also Mondal et al., 2010a). Although envisaged, no attempt was made so far for its testability. Here, we have made an attempt to show that these two frequency distributions can be used as an indicator of species' adaptation against shell breaks.

In order to clarify our understanding, a hypothetical schematic figure has been proposed (Figure 7). The figure represents a model of frequency distribution of length at the incidence of scarring $\left(L_{\text {scar }}\right)$ versus the frequency distribution of length at death $\left(L_{\text {death }}\right)$ for three hypothetical time intervals, with phase I being the oldest (Figure 7). Here, the $L_{\text {death }}$ represents distribution of length of all collected specimens, and the $\mathrm{L}_{\text {scar }}$ indicates the length when the individuals suffered breakage (e.g., the vulnerable growth stage of the species), irrespective of the agent of breakage involved. In addition, the figure shows which types of scars (Grade I, II, or III in our nomenclature) are most frequent at different intervals of time (see below). These three hypothetical time intervals are the phases of species' adaptation against shell breaking agents and may have evolutionary consequences (escalation, sensu Vermeij, 1987; see also Vermeij, 1982). Species-specific examples from Alexander and Dietl (2001; reproduced here in the right column of Figure 7), along with our present data, have been compared with these three phases. In this way, these three hypothetical time intervals can be considered as successive snapshots of species' adaptation at three time phases. The main goal is to show how a species with most of the breakage concentrated at the early ontogeny will try to adapt against shell-breaking causes and then how it affects survivorship of the species. The assumption that most of the scars are concentrated at the early ontogeny in our hypothetical figures is logical, because, with attainment of larger size and thicker shells, the individuals will be more resistant against either biotic or abiotic shell breaks. Many studies also confirm this type of distribution of $L_{\text {scar }}$ for bivalves (see Alexander and Dietl, 2001 for numerous examples).

Phase I is the earliest phase of adaptation, where the most severe type of breaks (Grade I) dominates (Figure 7). If shell breaking causes mortality at early ontogeny, we should expect more dead specimens at that ontogeny. In this case, the $L_{\text {death }}$ should have a left tail overlapping the distribution of $L_{\text {scars }}$ (Figure 5, Phase I in Figure 7, see also Alexander and Dietl, 2001), and the long-term survival and reproduction of the species will be difficult. In contrast, if breaks are not causing significant death, all these individuals carrying scars will survive up to the older ages. In that case, distributions of $L_{\text {scars }}$ and $L_{\text {death }}$ will have no or low overlap (Phase III in Figure 7). In order to reduce this juvenile loss, the species will attain a size refuge identified by an increased separation of the distributions of $L_{\text {scars }}$ and $L_{\text {death }}$ with time (from Phase I onwards in Figure 7). Such a separation can be achieved by increasing growth rate in order to reduce early ontogeny and exposure time to shelldamaging agents during this vulnerable age. Otherwise, shell thickness or shell ornamentation would increase without reducing the overlap between $L_{\text {scars }}$ and $L_{\text {death }}$ distributions. Individuals with these traits would have more chances of survival and eventually reproduce more. This may ensure adaptive changes in the future species population (Vermeij, 1982). In that case, the species, in the long run, will have less frequent severe damages (Phase III in Figure 7).

Similar adaptation can be identified in many bivalve species (Figure 7; see also figures in Alexander and Dietl, 2001). In all of the examples of Alexander and Dietl (2001), frequency distributions of $\mathrm{L}_{\text {scars }}$ and $\mathrm{L}_{\text {death }}$, shell breaks are mostly shifted towards the early part of ontogeny. Some of the species have distinct $L_{\text {scars }}$ and $L_{\text {death }}$ distributions (for example, Ensis directus, Mya arenaria; see 7.1-3, Phase III in our Figure 7), while other species have strongly overlapping $L_{\text {scars }}$ and $L_{\text {death }}$ distributions (for example, for Anadara ovalis, Mercenaria mercenaria, etc.; see Phase I and II in our Figure 7). Most of these species have thick shells, which imply better adaptation against shell damage 


\section{Life-history Graph}

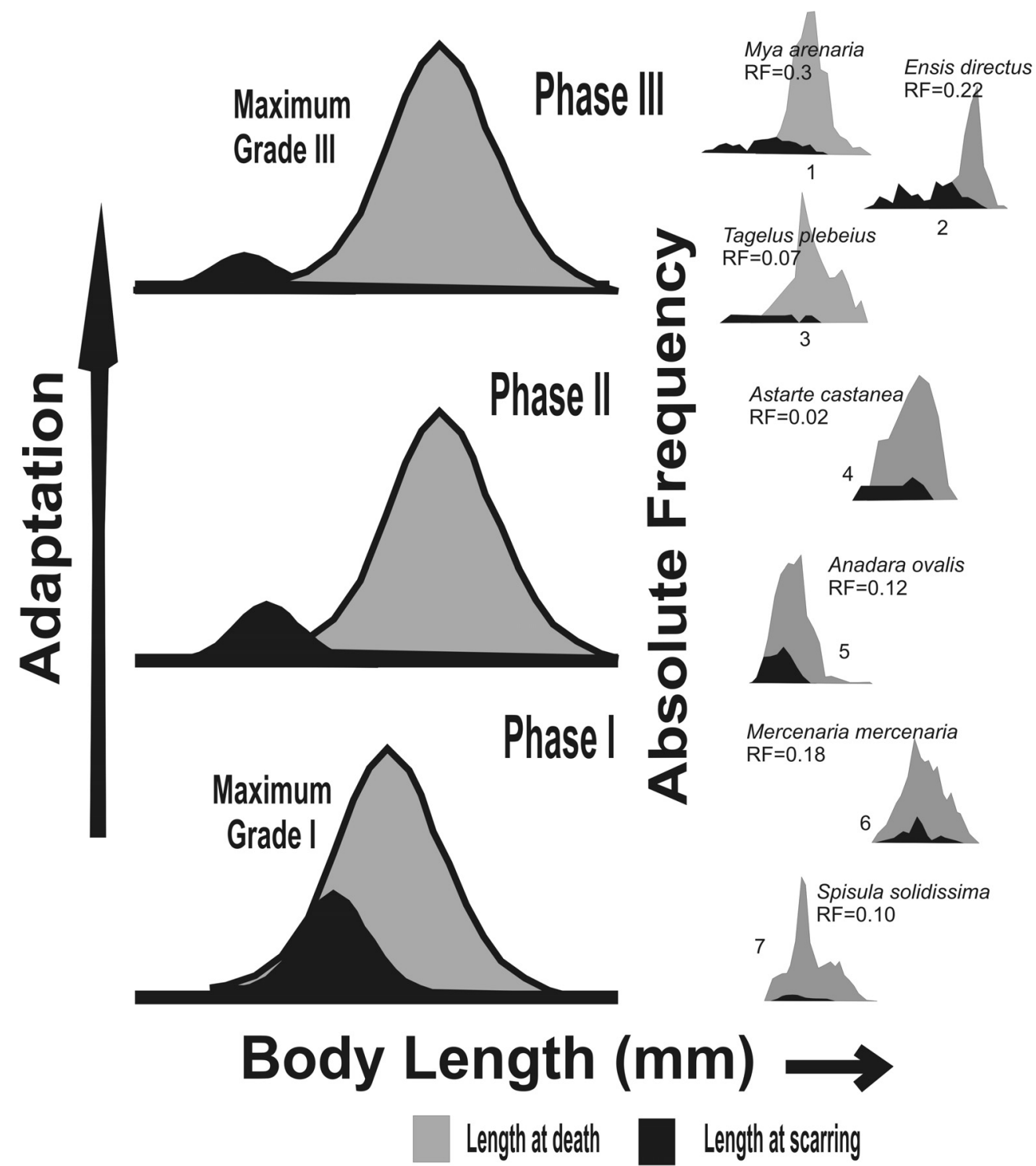

FIGURE 7. The model shows (left column) how species' adaptation allows it to reduce frequencies of severe damages with time (i.e., from Phase I to Phase III). In addition to it, the model also shows how death due to scarring is minimized by moving away from the frequency distribution of length at scarring (see text). The right column presents many examples of these distributions, redrawn from Alexander and Dietl (2001).

even when there is high chance of early death by shell breaks. In order to maximize survival by reducing lethal breaks (i.e., Grade I) at the early ontogeny, the different bivalve taxa showed different adaptations. If those adaptations (escalation) involve size refuge from lethal shell breaks at the early ontogeny, the distribution of $\mathrm{L}_{\text {scars }}$ will be similar to Phase III in Figure 7 (also see Figure 5), which will eventually determine an individual's long-term survival. According to Vermeij (1982), when some of these individuals survive sub-lethal attacks and reproduce, those adaptations will be favored by natural selection over individuals who do not have anti-breaking adaptations. In the evolutionary time scale, such traits will propagate among the population/species (Vermeij, 1982). 
In the present study, for $M$. violacea, we have observed that the $L_{\text {scars }}$ and $L_{\text {death }}$ distributions overlap (Figure 5), but show ontogenetic increase in shell thickness (Figure 6). It is possible that ontogenetic increase in thickness might increase the repair scar frequency with increasing size since thicker shells would be more likely to survive attack and become more resistant to damage. In addition, the present species becomes relatively deeper burrower during ontogeny as evident from relative increase of depth of pallial sinus. This further reduces the chance of encountering shell breaking predators, saltating clasts, or other causes of breakage. This adaptive success is coincident with the high frequency of very low grade, less severe damage on it (Table 2). All of these escalated morphological traits have enabled $M$. violacea to live longer and achieve a larger body size.

\section{ACKNOWLEDGEMENTS}

We express our sincere thanks to A. Kayal, M. Kayal, and R. Mitra for their cooperation in the fieldwork. S.M. acknowledges G. Herbert (University of South Florida) and two anonymous reviewers for valuable suggestions. The language of the manuscript is greatly improved by the careful proofreading by G. Brown (University of South Florida). S.B. acknowledges partial support from CAS of Department of Geological Sciences; DSTPURSE and UPE II of Jadavpur University. S. Mallick acknowledges the grant for field work funded by UGC.

\section{REFERENCES}

Alexander, R.R. 1986. Resistance to repair of shell breakage induced by durophages in Late Ordovician brachiopods. Journal of Paleontology, 60:273-285.

Alexander, R.R. and Dietl, G.P. 2001. Shell repair frequencies in New Jersey bivalves: a Recent baseline for tests of escalation with Tertiary, Mid-Atlantic congeners. Palaios, 16:354-371.

Alexander, R.R. and Dietl, G.P. 2003. The fossil record of shell breaking predation on marine bivalves and gastropods. p. 141-176. In Kelley, P.H., Kowalewski, M., and Hansen, T.A. (eds.), Predator-Prey Interactions in the Fossil Record. Kluwer Academic/Plenum Publishers, New York.

Alexander, R.R. and Dietl, G.P. 2005. Non-predatory shell damage in Neogene Western Atlantic deep-burrowing bivalves. Palaios, 20:280-295.

Ausich, W.I. and Gurrola, R.A. 1979. Two boring organisms in a Lower Mississippian community of southern Indiana. Journal of Paleontology, 53:335-344.
Boulding, E.G. 1984. Crab-resistant features of shells of burrowing bivalves: decreasing vulnerability by increasing handling time. Journal of Experimental Marine Biology and Ecology, 76:201-223.

Bromley, R.G. 1970. Borings as trace fossils and Entobia cretacea Portlock, as an example. Geological Journal Special Issue, 3:49-90.

Cadee, G.C. 1999. Shell damage and shell repair in the Antarctic limpet Nacella concinna from King George Island. Journal of Sea Research. 41:149-161.

Cadee, G.C., Walker, S.E., and Flessa, K.W. 1997. Gastropod shell repair in the intertidal of Bahia la Choya (N. Gulf of California). Palaeogeography, Palaeoclimatology, Palaeoecology, 136:67-78.

Carter, R.M. 1968. On the biology and palaeontology of some predators of bivalves Mollusca. Palaeogeography, Palaeoclimatology, Palaeoecology, 4:29-65.

Checa, A. 1993. Non-predatory shell damage in Recent deep-endobenthic bivalves from Spain. Palaeogeography, Palaeoclimatology, Palaeoecology, 100:309331.

Das, A., Mondal, S., and Bardhan, S. 2014. A note on exceptionally high confamilial naticid drilling frequency on Natica gualteriana from the Indian subcontinent. Historical Biology. 26:758-764.

Dietl, G.P. 2003. Coevolution of a marine gastropod predator and its dangerous bivalve prey. Biological Journal of the Linnean Society, 80:409-436.

Dietl, G.P. 2004. Origins and circumstances of adaptive divergence in whelk feeding behavior. Palaeogeography, Palaeoclimatology, Palaeoecology, 208:279291.

Dietl, G.P. and Alexander, R.R. 2005. High frequency and severity of breakage-induced shell repair in western Atlantic Pinnidae (Bivalvia). Journal of Molluscan Studies, 71:307-311.

Dietl, G.P. and Kelley, P.H. 2006. Can naticid gastropod predators be identified by the holes they drill? Ichnos. 13:103-108.

Dietl, G.P., Alexander, R.R., and Bien, W. 2000. Escalation in Late Cretaceous-early Paleocene oysters (Gryphaeidae) from the Atlantic Coastal Plain. Paleobiology, 26:215-237.

Ebbestad, J.O.R. and Peel, J.S. 1997. Attempted predation and shell repair in Middle and Upper Ordovician gastropods. Journal of Paleontology. 71:1007-1019.

Flessa, K.W., Cutler, A.H., and Meldahl, K.H. 1993. Time and taphonomy: quantitative estimates of time-averaging and stratigraphic disorder in a shallow marine habitat. Paleobiology, 19:266-286.

Grey, M., Boulding, E.G., and Brookfield, M.E. 2007. Shape differences among boreholes drilled by three species of naticid gastropods. Journal of Molluscan Research, 71:253-256.

Grey, M., Lelievre, P.G., and Boulding, E.G. 2005. Selection for prey shell thickness by the naticid gastropod Euspira lewisii (Naticidae) on the bivalve Protothaca staminea (Veneridae). The Veliger. 48:317-322. 
Ingole, B. 2002. Benthic Life on the Tropic Sandy Shore: Miramar Beach a Case Study. Recent Advances in Environmental Science. Discovery Publishing House, New Delhi.

Kowalewski, M. 2002. The fossil record of predation: an overview of analytical methods. Paleontological Society Special paper, 8:2-40.

Kowalewski, M., Flessa, K.W., and Marcot, J.D. 1997. Predatory scars in the shells of a Recent lingulid brachiopod: Paleontological and ecological implications. Acta Palaeontologica Polonica, 42:497-532.

Laxmilatha, P., Surendranathan, V.G., and Sivadasan, M.P. 2010. Biology of Mactra violacea (Gmelin 1791) from Kerala, south-west coast of India. Marine Fisheries Information Service T\&E Series, 203:18-19.

Leighton, L.R. 2001. New directions in the paleoecology of Paleozoic brachiopods, p. 185-206. In Carlson, S.J. and Sandy, M.R. (eds.), Brachiopods Ancient and Modern: a Tribute to G. Arthur Cooper. Yale University Reprographics and Imaging Services, New Haven, CT, USA.

Mondal, S. and Herbert, G.S. 2012. Effect of extinction on durophagy: a case study from the Neogene of Florida. Geological Society of America Abstract with program, 44:270.

Mondal, S., Bardhan, S., and Sarkar, D. 2010b. Testability of Energy Maximization Model (Kitchell et al., 1981) of naticid predation on two bivalve prey from eastern coast of India. The Nautilus. 124:1-14.

Mondal, S., Herbert, G.S., and Bardhan, S. 2010a. Analyzing repairability of shell breakage in bivalves. Geological Society of America Abstracts with Programs. 42:98.

Mondal, S., Herbert, G.S., Hutchings, J.A. 2014a. A note on edge drilling predation by naticid gastropods. Journal of Molluscan Studies. 80:206-212.

Mondal, S., Harries, P.J., Paul, S., and Herbert, G.S. 2014 b. Paleoecological significance of coupling metrics of successful and unsuccessful shell-breaking predation: examples using Neogene bivalve prey. Palaeogeography, Palaeoclimatology, Palaeoecology. 399:89-97.

Morton, B. 2005. Predator-prey interaction between Lepsiella (Bedeva) paive (Gastropoda: Muricidae) and Kateysia scalarina (Bivalvia: Veneridae) in Princess Royal Harbour, Western Australia. Journal of Shellfish Research, 71:371-378.

Paul, G., Das, A., Bardhan, S., and Mondal, S. 2013. Predation on Recent Turritelline Gastropods from the Indian Subcontinent and Comparison with a Revised Global Database. Malacologia, 56:193-213.
Ramsay, K., Richardson, C.A., and Kaiser, M.J. 2001. Cause of shell scarring in the dog cockles Glycymeris glycymeris L. Journal of Sea Research, 45:131-139.

Ramsay, K., Kaiser, M.J., Richardson, C.A., Veale, L.O., and Brand, A.R. 2000. Can shell scars on dog cockles (Glycymeris glycymeris L.) be used as indicators of fishing disturbance? Journal of Sea Research, 43:167-176.

Rao, S.N.V., Dey, A., and Barua, S. 1992. Fauna of West Bengal (part 9). Zoological Survey of India Kolkata, India.

Rao, S.N.V., Rao, S.K.V., and Mitra, S. 1991. Fauna of Orissa (Part 3). Zoological Survey of India, Kolkata, India.

Sanford, E., Roth, M.S., John, G.C., Wares, J.P. and Somero, G.N. 2003. Local selection and latitudinal variation in a marine predator-prey interaction. Science 300, 1135-1137.

Seed, R. and Hughes, R.N. 1995. Criteria for prey sizeselection in molluscivorous crabs with contrasting claw morphologies. Journal of Experimental Marine Biology and Ecology, 193: 177-195.

Stanley, S.M. 1970. Relation of shell form to life habits of the Bivalvia (Mollusca). Geological Society of America, Memoire, Boulder, Colorado.

Vermeij, G.J. 1977. The Mesozoic marine revolution: evidence from snails, predators and grazers. Paleobiology, 3: 245-258.

Vermeij, G.J. 1982. Unsuccessful predation and evolution. The American Naturalist, 120:701-720.

Vermeij, G.J. 1983. Traces and trends of predation with special reference to bivalved animals. Palaeontology, 26:455-465.

Vermeij, G.J. 1987. Evolution and Escalation: An Ecological History of Life. Princeton University Press, Princeton, N.J.

Vermeij, G.J. and Dudley, E.C. 1985. Distribution of adaptations: a comparison between the functional shell morphology of freshwater and marine pelecypods. p. 461-478. In Trueman, E.R., and Clarke, M.R. (eds.), The Mollusca, Evolution: Academic Press, New York.

Zipser, E. and Vermeij, G.J. 1978. Crushing behavior of tropical and temperate crabs. Journal of Experimental Marine Biology and Ecology, 31:155-172.

Zuschin, M., Stachowitsch, M., and Stanton, Jr., R.J. 2003. Patterns and processes of shell fragmentation in modern and ancient marine environments. EarthScience Reviews, 63:33-82. 